\title{
1,3,4-thiadiazole Attached 2, 3- disubstituted Thiazolidinones Derivatives: Synthesis and Biological Evaluation
}

\author{
Ashish Garg', Sweta Garg ${ }^{2, *}$ \\ ${ }^{1}$ Department of PG Studies and Research in Chemistry and Pharmacy, Rani Durgawati University, Jabalpur, Madhya Pradesh, INDIA. \\ ${ }^{2}$ Shri Ram Institute of Pharmacy, Jabalpur, Madhya Pradesh, INDIA.
}

\begin{abstract}
Background: Thiazolidinone derivatives are the subject of prominent importance since they have been seen as valuable intermediates for the formulating/synthesize of different heterocyclic derivatives and it gives various subsidiaries with every extraordinary kind of exercise. What're more, researches show that derivatives having 1,3,4-Thiadiazole core/ nucleus have a wide scope of pharmacological potential that incorporates antifungal, antibacterial, antiviral, anticancer, antitubercular, anticonvulsant, antidiabetic and antioxidant. From the literature reviewed, both the nucleus was found to be active as antimicrobials, anti-inflammatory as well as anticancer agents. Materials and Methods: It has been planned to synthesize "1,3,4-thiadiazolyl-thiazolidin-4-one" derivatives and evaluate their biological activities. The novel subordinates $(4 a-4 j)$ of 2,3 -disubstituted Thiazolidinones were integrated into acceptable yield by the synthesis of benzaldehyde with thiosemicarbazide to provide thiosemicarbazones, 1,3,4-thiadiazoles is then produced by thiosemicarbazone cyclized by involving ferric chloride. By the reaction of various aromatic aldehyde with 1,3,4-thiadiazoles yielded different Schiff bases. The final derivative 2-aryl-3-(5-aryl-1,3,4-thiadiazol-2-yl)- 1,3-thiazolidine-4-one was obtained by the reaction between the schiff base with thioglycolic acid. All subordinates/ derivatives were portrayed by spectral analysis examination (IR, 1H NMR) and elemental analysis and then screened for biological activities (in-vitro anticancer, antimicrobial, anti-inflammatory). Results and Conclusion: The analysis reveals that synthesized derivatives of thiazolidinone possessing methyl, hydro, nitro, hydroxyl, flouro, chloro, methoxy, dimethoxy and amino substitution through phenyl ring. All these groups help pharmacophore, to increase their pharmacological activities. However, the substituted phenyl ring in the side chain also facilitates the biological action of the molecules. The increased activity of the new derivatives explains that they act as a more powerful and potent bioactive molecule when compare with the standard drug. This significant activity may be due to the substitution in the $2^{\text {nd }}$ position of thiazolidinone nucleus. As result, all the tested compounds exhibit good activity and compounds $4 i, 4 b, 4 f$ and $4 a$ were established more noteworthy and outstanding as of all the derivatives.
\end{abstract}

Key words: Schiff base, Thiazolidinone, 1,3,4-Thiadiazole, Molecular docking, Antiinflammatory, Antimicrobial, Anti-cancer.

\section{INTRODUCTION}

Thiazole derivatives are the most precious classes of heterocyclic compounds because of their medicinal importance; their derivatives are characterized by high biological activity in pharmaceutical fields and have shown various pharmacological activities. Thiazolidine is a tetrahydro derivative of thaiazole and the 'oxo' derivative of thiazolidine is identified as thiazolidinone. ${ }^{1}$ A great deal of research chip away at thiazolidinones has been done in quite a while in the past. The center/core is otherwise called magic moiety (wonder nucleus) since it gives out various derivatives with
Submission Date: 04-04-2021; Revision Date: 28-07-2021; Accepted Date: 08-10-2021

DOI: 10.5530/ijper.55.4.215 Correspondence:

Dr. Sweta Garg, Shri Ram Institute of Pharmacy, Jabalpur, 482002, Madhya Pradesh, INDIA. Phone: 0-91-9806106629, Email - swetagarg2@gmail. com

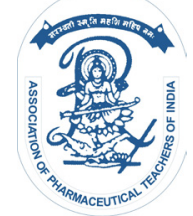

www.ijper.org 
every single distinctive sort of pharmacological event. ${ }^{2}$ Thiazolidinone subordinates are the subject of famous intrigue since they have been seen as helpful intermediates for the create/synthesize of different heterocyclic compounds. ${ }^{3}$ Thiazolidinones, which are the derivatives of thiazolidine, belongs to an essential group of heterocyclic compounds containing sulfur and nitrogen in a five-member ring. ${ }^{4}$ 1,3-Thiazolidin-4-ones are heterocycles that have an atom of sulfur at position 1 , an atom of nitrogen at position 3 and a carbonyl group at position 4. Replacement can occur at 2, 3 and 5 positions. $^{2}$ For the planning of potential bioactive, a Thiazolidin-4-one an adaptable platform. Thiazolidin4-one compounds accounted for an expansive range of pharmacological activity, for example anticancer, cell reinforcement, antimicrobial, ${ }^{6}$ anti-inflammatory, ${ }^{5}$ and anti-HIV, ${ }^{7}$ anticonvulsant, ${ }^{8}$ and cardioprotective activities. $^{9}$

Due to this bioactivity and pharmacological impact of the compound and in the persistence of our ongoing study on heterocyclic compounds, we decided to synthesize a novel series of thiazolidin-4-one" derivatives, in which 1,3,4-Thiadiazole nucleus was added as intermediate. Writing demonstrates that a molecule having 1,3,4-Thiadiazole core has a wide scope of pharmacological exercises that incorporate antifungal, ${ }^{10}$ antibacterial, ${ }^{11}$ antiviral, anti-inflammatory, ${ }^{12}$ antitubercular, ${ }^{13,14}$ painrelieving, antileishmanial, antiepileptic, CNS depressant, anticancer, ${ }^{15}$ anticonvulsant, cell reinforcement, diuretic, ${ }^{16}$ molluscicidal, antidiabetic, ${ }^{17}$ and antihypertensive. ${ }^{18}$

From the scientific works, both the nucleus was found to be active as anticancer, antimicrobials and antiinflammatory agents. It has been planned to synthesize "1,3,4-thiadiazolyl-thiazolidin-4-one" derivatives. The different Schiff bases were yielded on the treatment of 2-amino-5-aryl 1,3,4-thiadiazoles with aromatic aldehydes, which were cyclized by reaction with thioglycolic acid using N,N'-Dicyclohexylcarbodiimide (DCC) as dehydrating agents and evaluate them for their biological activity (i.e. anticancer, antimicrobials and anti-inflammatory agents).

\section{Experimental}

By utilizing the TLC plate method, the compound response was identified and evaluated by introducing benzene-ethanol (8:2) as a solvent system and applying ultraviolet light on the TLC plate, the compounds were spotted/identified in presence of iodine fumes. By utilizing digital melting point apparatus, the melting points of the various synthesized derivatives were identified. The FTIR method (Cary-60, Agilent Technologies, USA) was employed to characterize the various groups (i.e. $\mathrm{C}=\mathrm{O}, \mathrm{NH}$ spectra etc.). Moreover, the other essential characteristics of the prepared synthesized compounds were characterized using NMR spectral estimation involving ${ }^{1} \mathrm{H}$ and ${ }^{13} \mathrm{C}$ NMR spectra (Bruker DPX-300 MHz), $\mathrm{CDCl}_{3}$ was utilized as a solvent system in this spectral analysis and Mass spectra (LCMS/MS-Applied Bio-system, USA). Rather then, the other essential chemicals involved in the duration of the synthesis procedure were purchased from Sigma Aldrich, USA; Himedia Laboratory (MS), India.

\section{Synthesis of Thiosemicarbozone}

$0.2 \mathrm{M}$ Aromatic aldehyde was dissolved in $300 \mathrm{ml}$ of warm ethanol. $0.2 \mathrm{M}$ of Thiosemicarbazide was dissolved in $300 \mathrm{ml}$ of hot water. Both the solutions were mixed slowly with continuous stirring. After cooling, the separated crystals of the product (thiosemicarbazone) were filtered off. The purity of the compound was monitored by TLC and melting point determination. ${ }^{19}$

\section{Amalgamation of 2-Amino-5-Aryl-1,3,4-Thiadiaozles}

$0.05 \mathrm{M}$ of Thiosemicarbazone was suspended in $300 \mathrm{ml}$ of double-distilled water in a beaker. Ferric chloride $(0.15 \mathrm{M})$, disintegrated in $300 \mathrm{ml}$ of (distilled water) DW and then included in thiosemicarbazone dispersion. It was warmed to $80-90^{\circ} \mathrm{C}$ and kept up for $45 \mathrm{~min}$ and afterward, the dispersion was filtered. A blend of citrus acid $(0.11 \mathrm{M})$ and sodium citrate $(0.05 \mathrm{M})$ was added to the above dispersion and mixed gently using a homogenizer. Subsequent to cooling, the prepared reaction was neutralized with $10 \%$ of the ammonia solution. The precipitate then acquired was separated and washed with DW and permitted to dry then recrystallized by using $40 \%$ ethanol. ${ }^{20}$

\section{Synthesis of Schiff Bases}

$0.02 \mathrm{M}$ of the amino-thiadiazole was dissolved in $10 \mathrm{ml}$ of absolute ethanol by heating and stirring. Then, $0.02 \mathrm{M}$ appropriate aldehyde in $10 \mathrm{ml}$ ethanol was added to it, with stirring. Then refluxed it for 3-4 hr. The crystals obtained on cooling were filtered and dried. The purity of the compounds were monitored by TLC and melting point determination. ${ }^{21}$

\section{Synthesis of 4-Thiazolidinone Derivatives}

$0.01 \mathrm{M}$ of the Schiff base was included in $100 \mathrm{ml}$ of benzene, subsequently, $0.01 \mathrm{M}$ thioglycolic acid and $0.01 \mathrm{M}$ dicyclohexylcarbodiimide (DCC) was included. The dispersion was refluxed for $6 \mathrm{hr}$. At that point the concentrated the above dispersion utilizing vacuum evaporation. The concentrate was neutralized by the addition of $\mathrm{NaHCO}_{3}$ solution (10\%) and the precipitate acquired was separated by filtration and dried. ${ }^{22-24}$ 
Spectral analysis of synthesized compound Thiosemicarbazone(I)

IR- 1267 (C=S), 1452 ( $\mathrm{C}=\mathrm{C}$ Stretch), 1520 (C=N Stretch), 3060(C-H Stretch). ${ }^{1} \mathrm{H}$ NMR- 2.0, 8.1, 7.6, 7.3. ${ }^{13} \mathrm{C}$ NMR- 181.4, 143.0, 133.8, 129.2.m/e: 179.5. Elemental analysis $\left(\mathrm{C}_{8} \mathrm{H}_{9} \mathrm{~N}_{3} \mathrm{~S}\right): \mathrm{N}, 23.44 ; \mathrm{S}, 17.89, \mathrm{H}, 5.06 ; \mathrm{C}, 53.61$; found $\mathrm{N}: 22.53, \mathrm{H}: 4.68$, C:52.45.

\section{1,3,4-thiadiazole (II)}

IR- 1740(C=O), $1634(\mathrm{C}=\mathrm{N}), 1423(\mathrm{C}=\mathrm{C}) 3111(\mathrm{C}-\mathrm{H})$. ${ }^{1} \mathrm{H}$ NMR- 7.48, 7.32, 7.22, 4.0. ${ }^{13} \mathrm{C}$ NMR- 161.6, 127.5, 129.3, 128.8, 133.5.m/e: 193.2. Elemental analysis $\left(\mathrm{C}_{9} \mathrm{H}_{11} \mathrm{~N}_{3} \mathrm{~S}\right): \mathrm{N}, 21.74 ; \mathrm{H}, 5.74 ; \mathrm{C}, 55.93$, found $\mathrm{N}: 20.16$, H: 3.11, C: 54.83,

2-phenyl-3-(5-phenyl-1,3,4-thiadiazol-2-yl)thiazolidin-4one.(4a)

IR- 1636, $1458(\mathrm{C}=\mathrm{C}) 1663(\mathrm{C}=\mathrm{O}), 1544$ (C=N Stretch), 3134 (C-H Stretch). ${ }^{1} \mathrm{H}$ NMR- 5.92, 7.06, 7.14, 7.48, 7.32. ${ }^{13} \mathrm{C}$ NMR- 127.2, 128.7, 139.2, 171.2, 65.3, 33.6, 163.4, 175.0, 133.5.m/e: 339.5. Elemental analysis $\left(\mathrm{C}_{17} \mathrm{H}_{13} \mathrm{~N}_{3} \mathrm{OS}_{2}\right): \quad \mathrm{C}: \quad 61.45, \mathrm{H}: 3.53, \mathrm{~N}: 12.53$, found C:60.15, H:3.86, N:12.38.

2-(4-(dimethylamino)phenyl)-3-(5-phenyl-1,3,4thiadiazol-2-yl)thiazolidin-4-one.(4b)

IR- 1610, 1458 (C=C Stretch), 1217, $1284\left(\mathrm{~N}_{-} \mathrm{CH}_{3}\right.$ Stretch), 1683 (C=O Stretch), 1521 (C=N Stretch), 3018 (C-H Stretch). ${ }^{1} \mathrm{H}$ NMR- 2.85, 6.47, 6.88, 5.92, 7.48, 7.32. ${ }^{13} \mathrm{C}$ NMR- 40.3, 148.0, 114.2, 129.7, 128.7, 65.3, 171.2, 163.4, 175.0, 127.5, 129.3.m/e: 382.9; Elemental analysis $\left(\mathrm{C}_{19} \mathrm{H}_{18} \mathrm{~N}_{4} \mathrm{OS}_{2}\right)$ : C: $60.45, \mathrm{H}: 4.53, \mathrm{~N}: 13.53$, found C:59.66, H: 4.74, N:14.65.

2-(2, 3-dimethoxyphenyl)-3-(5-phenyl-1,3,4-thiadiazol-2yl)thiazolidin-4-one(4c)

IR-1319, 1280 (C-O Stretch), 3062 (C-H Stretch), 1627, 1442 (C=C Stretch), 1666 (C=O Stretch), 1517 (C=N Stretch), ${ }^{1} \mathrm{H}$ NMR- 3.73, 6.47, 6.59, 6.51, 5.92, 7.48, 7.32, 7.22. ${ }^{13} \mathrm{C}$ NMR- 56.2, 56.5, 149.7, 113.7, 150.2, 117.6, 163.4, 175.0, 133.5, 128.8.m/e: 399.07; Elemental analysis $\left(\mathrm{C}_{19} \mathrm{H}_{17} \mathrm{~N}_{3} \mathrm{O}_{3} \mathrm{~S}_{2}\right)$ : C: $57.45, \mathrm{H}: 4.53, \mathrm{~N}: 11.03$, found C: $57.12, \mathrm{H}: 4.29, \mathrm{~N}: 10.52$.

2-(4-chlorophenyl)-3-(5-phenyl-1,3,4-thiadiazol-2-yl) thiazolidin-4-one(4d)

IR- 1045 (C-Cl Stretch),3066 (C-H Stretch), 1616, 1444 (C=C Stretch), 1699 (C=O Stretch), 1527 (C=N Stretch). ${ }^{1} \mathrm{H}$ NMR- 7.15, 7.00, 5.92, 3.33, 7.38, 7.32, 7.22. ${ }^{13} \mathrm{C}$ NMR- 132.7, 128.8, 130.2, 137.3, 65.3, 171.2, 163.4, 175.0, 133.5, 127.5, 129.3, 128.8. m/e: 373.1, Elemental analysis $\left(\mathrm{C}_{17} \mathrm{H}_{12} \mathrm{ClN}_{3} \mathrm{OS}_{2}\right): \mathrm{C}: 54.95, \mathrm{H}: 3.82, \mathrm{~N}: 11.53$, found C: 53.61, H: 3.24, N:11.24. 2-(4-nitrophenyl)-3-(5-phenyl-1,3,4-thiadiazol-2-yl) thiazolidin-4-one.(4e)

IR-, 1544, 1376 (C-NO Stretch), 1508 (C=N Stretch), 3132 (C-H Stretch), 1608, 1409 (C=C Stretch), 1637 (C=O Stretch). ${ }^{1} \mathrm{H}$ NMR- 8.07, 7.32, 5.92, 3.38, 7.48, 7.32,7.22. ${ }^{13} \mathrm{C}$ NMR- 146.8, 121.0, 129.7, 145.3, 171.2, 163.4, 175.0, 127.5.m/e: 384.04, Elemental analysis $\left(\mathrm{C}_{17} \mathrm{H}_{12} \mathrm{~N}_{4} \mathrm{O}_{3} \mathrm{~S}_{2}\right): \mathrm{N}: 15.03, \mathrm{H}: 4.53, \quad \mathrm{C}: 53.45$, found $\mathrm{N}: 14.57, \mathrm{H}: 3.15$, C:53.11.

2-(4-hydroxyphenyl)-3-(5-phenyl-1,3,4-thiadiazol-2-yl) thiazolidin-4-one.(4f)

IR- 3132 (C-H Stretch), 1601, 1412 (C=C Stretch), 3460(O-H Stretch), 1520 (C=N Stretch), $1640(\mathrm{C}=\mathrm{O}$ Stretch). ${ }^{1} \mathrm{H}$ NMR- 6.61, 6.89, 5.92, 7.48, 7.32, 7.22. ${ }^{13} \mathrm{C}$ NMR- 115.8, 130.2, 131.8, 130.2, 171.2, 163.4, 175.0, 128.8, $129.3 . \mathrm{m} / \mathrm{e}: 355.04$, Elemental analysis $\left(\mathrm{C}_{17} \mathrm{H}_{13} \mathrm{~N}_{3} \mathrm{O}_{2} \mathrm{~S}_{2}\right): \mathrm{C}: 56.65, \mathrm{H}: 3.91, \mathrm{~N}: 12.58$, found $\mathrm{C}$ : 57.45, H: 3.69, N: 11.82 .

\section{2-(4-methoxyphenyl)-3-(5-phenyl-1,3,4-thiadiazol-2-yl) thiazolidin-4-one(4g)}

IR- 1300 (Ar-C-N Stretch), 1512 (C=N Stretch),1623 (C=C Stretch), 3145 (C-H Stretch), 1647 (C=O Stretch). ${ }^{1} \mathrm{H}$ NMR- 3.73, 6.65, 6.95, 5.92, 7.48, 7.32, 7.22. ${ }^{13} \mathrm{C}$ NMR- 55.9, 159.1, 114.2, 129.8, 131.5, 33.6, 171.2, 65.3, 163.4. m/e: 369.6 . Elemental analysis $\left(\mathrm{C}_{18} \mathrm{H}_{15} \mathrm{~N}_{3} \mathrm{O}_{2} \mathrm{~S}_{2}\right)$ : C: $57.45, \mathrm{H}: 3.22, \mathrm{~N}: 12.43$, found C: $58.52, \mathrm{H}: 4.09, \mathrm{~N}$ : 11.37 .

\section{3-(5-phenyl-1,3,4-thiadiazol-2-yl)-2-p-tolylthiazolidin-4- one.(4h)}

IR- 1505 (C=N Stretch), 1656, 1432 (C=C Stretch), 1631 (C=O Stretch), 3130 (C-H Stretch),. ${ }^{1} \mathrm{H}$ NMR- 6.94, 5.92, 3.38, 7.48, 7.32, 7.22. ${ }^{13} \mathrm{C}$ NMR- 136.8, 129.0, 128.7, $136.2,65.3,171.2,163.4,175.0,127.5,129.3,128.8 . \mathrm{m} / \mathrm{e}:$ 353.7. Elemental analysis $\left(\mathrm{C}_{18} \mathrm{H}_{15} \mathrm{~N}_{3} \mathrm{OS}_{2}\right)$ : C: 62.45 , $\mathrm{H}: 5.53, \mathrm{~N}: 11.33$, found C: 61.16, H: 4.28, N:11.89.

\section{2-(4-aminophenyl)-3-(5-phenyl-1,3,4-thiadiazol-2-yl) thiazolidin-4-one.(4i)}

IR- 3152(N-H stretch), 1510 (C=N Stretch), 1645, 1409 (C=C Stretch), 3136 (C-H Stretch), 1622 (C=O Stretch). ${ }^{1} \mathrm{H}$ NMR- 6.34, 6.81, 5.92, 7.48, 7.32, 7.22, 7.48. ${ }^{13} \mathrm{C}$ NMR- 129.6, 116.2, 146.8, 116.2, 163.4, 171.2, 175.0, 127.5, 133.5, $128.3 . \mathrm{m} / \mathrm{e}: 354.06$, Elemental analysis $\left(\mathrm{C}_{17} \mathrm{H}_{14} \mathrm{~N}_{4} \mathrm{OS}_{2}\right): \mathrm{C}: 56.45, \mathrm{H}: 4.67, \mathrm{~N}: 14.53$, found $\mathrm{C}$ : 57.61, H: 3.98, N:15.81.

\section{2-(4-fluorophenyl)-3-(5-phenyl-1,3,4-thiadiazol-2-yl) thiazolidin-4-one(4j)}

IR- 945(Ar-C-F Stretch), 1501 (C=N Stretch), 3115 (C-H Stretch),1672, 1410 (C=C Stretch), 1627 (C=O Stretch). ${ }^{1} \mathrm{H}$ NMR- 6.85, 7.04, 5.92, 7.48, 7.32. ${ }^{13} \mathrm{C}$ NMR- 161.3, 
$115.4,130.4,134.8,171.2,163.4,133.5,127.5,129.3$ 128.8.m/e: 357.4 . Elemental analysis $\left(\mathrm{C}_{17} \mathrm{H}_{12} \mathrm{FN}_{3} \mathrm{OS}_{2}\right): \mathrm{C}$ : 57.12, H:3.53, N:11.53, found C: 57.43, H: 3.38, N:11.36.

\section{Biological evaluation}

\section{In vitro anticancer activity}

The SRB-based anticancer assay is an economical, easy and sensitive process to identify the cytotoxic capability of the test molecule. To get a large amount of cells, the acquired human breast cancer cells were grown, containing a suitable culture medium in $5 \% \mathrm{CO}_{2}$ with $\mathrm{RH}$ (relative humidity) $90 \%$ and temperature $\left(37^{\circ} \mathrm{C}\right)$. After grown of cells, the cell was treated with a trypsinEDTA solution and maintained the growth to 10,000 cells $/ 100 \mu \mathrm{l}$ in suspension, then the adequate amount of cell suspension $(100 \mu \mathrm{l})$ was taken in 96 well plates and incubated at the atmospheric condition mentioned above $\left(37^{\circ} \mathrm{C}, 5 \% \mathrm{CO}_{2}\right.$ and $\left.\mathrm{RH} 90 \%\right)$ for $24 \mathrm{hr}$. After then the different concentration of the test sample $(10,20,40$ and 80 microgram $/ \mathrm{ml})$ was added individually in a separate tube. Trichloric acid $(50 \mu 1-50 \%$ chilled solution) was then added into the well plate after $(48 \mathrm{~h})$ addition of sample. For fixation of cells, the plates were again incubated at $4{ }^{\circ} \mathrm{C}$ for $1 \mathrm{~h}$. Before the addition of SRB solution $(100 \mu \mathrm{l}$ SRB solution of $0.4 \% \mathrm{w} / \mathrm{v}$ in $1 \%$ acetic acid), the plates were washed and air dried, then the plates were placed for $30 \mathrm{~min}$ at room temperature and then washed with acetic acid solution (1\%) followed by air-dried. Tris buffer (100 $\mu \mathrm{l}$ of $10.5 \mathrm{M})$ was then added into the well plates and placed into a mechanical shaker for shaking for about 20 mins. After all the above process the cells (cell growth inhibition) was identified and evaluated by using ELISA reader for about $540 \mathrm{~nm} .^{25,26}$

\section{Antimicrobial assessment}

By comparison with standard drugs ampicillin and miconazole, the prepared series $(4 a-4 j)$ was found to be active as an antibacterial and antifungal moiety. ${ }^{27}$

\section{Evaluation of Antibacterial activity}

By utilizing various concentration range $(0.025 \mu \mathrm{g} / \mathrm{ml}$ to $2500 \mu \mathrm{g} / \mathrm{ml}$ ) of the synthesized derivatives (test compound) was preferred to characterize the antibacterial assay by agar well diffusion technique on Mueller Hinton agar media (bacterial nutrient medium) against Stapbylococus aureus (ATCC 10231), Escherichia coli (ATCC25922), Streptococcus pyogenes (MTCC 442) and Pseudomonas aeruginosa (ATCC 10145), DMSO utilized as control and Ampicillin drug was used as a standard against Gram-positive and Gram-negative bacteria.

\section{Evaluation of Antifungal Activity}

The synthesized compounds $(4 a-4 j)$ were screened for antifungal activity, at a different concentration of $(0.025 \mu \mathrm{g} / \mathrm{ml}$ to $2500 \mu \mathrm{g} / \mathrm{ml})$. The antifungal evaluation of the synthesized derivative was identified using Sabouraud dextrose media (fungal nutrient medium). DMSO was utilized as a control medium and Miconazole was used as a standard against Candida albicans ATCC 24433 and Aspergillusniger, ATCC 16888.

\section{Anti-inflammatory assay}

The anti-inflammatory potential of integrated mixes was assessed via the carragenan-prompted hind paw edema technique. ${ }^{28}$ The Institutional Animal Ethics Committee approval number for performing in-vivo assay is GRKIST/406/02/IAEC/16A. Ibuprofen was utilized as a source of perspective medication. The test was performed in the rat (using an animal model) and then the animal was separated into three different groups having 6 rats in each group. Group I was served as Control, II group was treated with the test sample, whereas the III group was utilized for standard treatment. In each animal, the aponeurosis was grown of the right hind paw by applied dispersion of carrageenan $(1 \%$ in $0.9 \%$ saline- $0.05 \mathrm{mn}$ ). One hour before treatment of carrageenan, the test sample and standard formulation were administered orally into the treated and standard group respectively. Before $1 \mathrm{hr}$ and after $3 \mathrm{hr}$ of the carrageenan administration, the paw volume of each animal was estimated by utilizing a plethysmometer. The $\%$ anti-inflammatory potential of the synthesized derivatives was determined by the equation shown beneath:

$$
\% \text { inhibition of edema }=\left(1-\mathrm{V}_{\mathrm{t}} / \mathrm{V}_{\mathrm{c}}\right) \times 100
$$

Here, the mean enhance in paw volume of rat in treated group represents as $\mathrm{V}_{\mathrm{t}}$ and for control group represented by $\mathrm{V}_{\mathrm{c}}$, respectively.

\section{Computational chemistry studies Molecular Docking study}

Molecular docking analysis was performed by utilizing the LibDock module in Discovery Studio 2.1, to examine the inhibitory activity and orientation of ligand against human DHFR. To estimate the anticancer activity, firstly, the synthesized compound was docked with the 3D structure of human DHFR (retrieved from the Protein Data Bank- PDB ID: 1DLS; http://www. rcsb.org) and afterward with the identified anticancer molecule (drug) Methotrexate. The pre-owned docking program LibDock produces a few represents, each 
delivering their relating LibDock scores with various directions inside the characterized effective site of the protein. The best ligand binding verification was characterized by an optimized high LibDock score of the ligand pose. At long last, the examine ligand (synthesized compound) poses subprotocol was performed to estimate hydrogen bonds and hydrogen bond distance (close contacts-Vander Waals conflicts between the test sample and human DHFR.

\section{ADMET prediction}

The compounds are analyzed by their respective toxicity and pharmacokinetic studies by utilizing the ADMET descriptors analysis protocol in DS.

\section{RESULTS AND DISCUSSIONS}

In our incessant effort to synthesize some novel thiazolidinone compounds active as anticancer, antimicrobial and anti-inflammatory agents, we report a series of thiadiazolylthiazolidizolinone derivatives. Inspection of the chemical structure of the target compounds revealed that the nucleus could be divided into two subunits: the thiazolidinone part and the thiadiazole part. The TLC analysis was a utility to characterize the purity of the compounds and the recrystallization of the compound was done utilizing the solvent-ethanol. The spectral assay NMR and IF was employed to characterize the spectral features of the various synthesized derivatives as well as the elemental analysis also been employed.

\section{Chemistry}

The scheme of synthesis of different thiazolidinone derivative shown in Figure 1. The synthesized derivatives of thiazolidinone possessing methyl, hydro, nitro, hydroxyl, flouro, chloro, methoxy, dimethoxy and amino substitution through phenyl ring (Table 1). All these groups help pharmacophore, to increase their pharmacological activities. However, the substituted phenyl ring in the side chain also facilitates the biological action of the molecules. ${ }^{29}$

In their similar investigation of the substituted group of the aryl moiety towards antibacterial potency, they observe that more activity was found in electronwithdrawing moiety and less activity was shown in the group having electrons donating moiety. ${ }^{30}$ Effect of electron-withdrawing groups present in the synthesized compounds on the result, is greater than our expectations. Our present study shows the importance of the effect of substitutions on the thiazolidinone moiety for their pharmacological properties.
Benzaldehyde

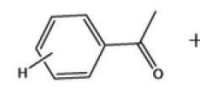

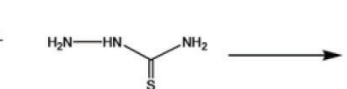

Thiosemicarbazide

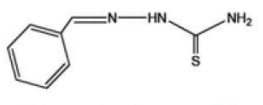

Thiosemicarbazone (I)
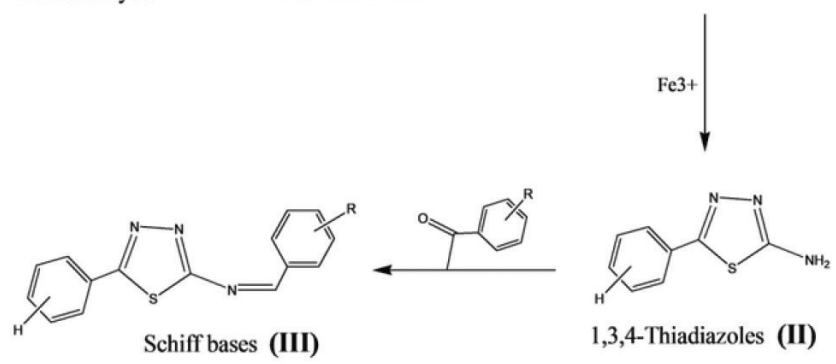

1,3,4-Thiadiazoles (II)

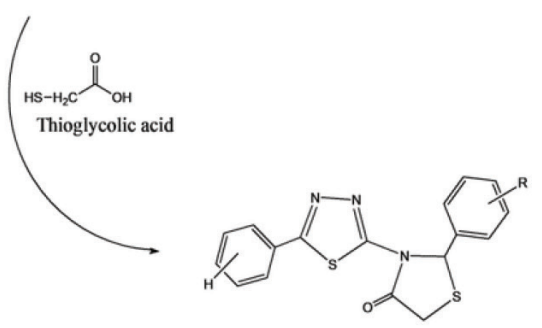

(IV)

Figure 1: Scheme of synthesis.

In systems containing more than two hetero atoms in the same ring, the trend of properties are found. In particular, the additional heteroatoms in both six- and five-membered systems leads to a suppression of electrophilic substitution and a slowing of electrophilic addition to nitrogen. On the other hand, further increase in tendencies for nucleophilic substitution and addition and the five-membered compounds, further increases in acidities of $\mathrm{N}$-hydrogen are found. ${ }^{31}$ Thiadiazoles are extremely weak bases because of the inductive impacts of the extra hetero molecules, despite the fact that $\mathrm{N}$-quarternized responses can be done. For comparative reasons, electrophilic replacements on carbon are for all intents and purposes obscure, aside from mercurations and halogenations. ${ }^{32}$

\section{In-vitro anticancer activity}

The human breast cancer cell lines (MCF-7) were utilized to predict the anticancer potential of the synthesized thiazolidinone derivatives $(4 a-4 j)$ by SRB assay. The cytotoxicity assessment suggests the dose-dependent manner of the system against cancer cells which justifies the decrement in cell viability by enhancing the sample (synthesized derivative) concentration. The outcome revealed by the assay was depicted in the graph (Figure 2), which suggested the higher concentration of synthesized derivative shows greater inhibitory action. Different derivatives (4a-4j) were observed to display enhanced cytotoxic effect with increasing the concentration range from $10,20,40$ and $80 \mu \mathrm{g} / \mathrm{ml}$. The 


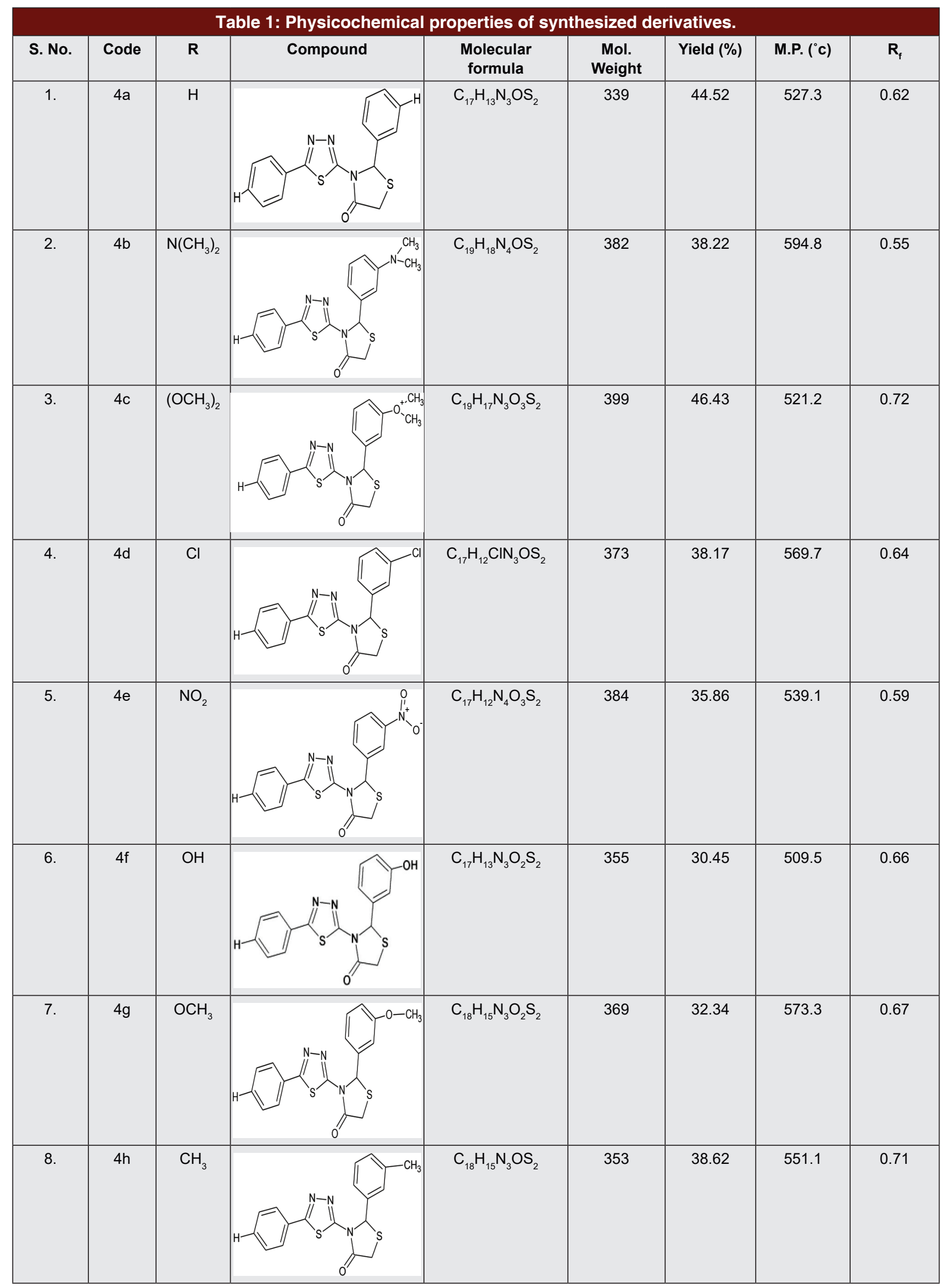

Continued... 


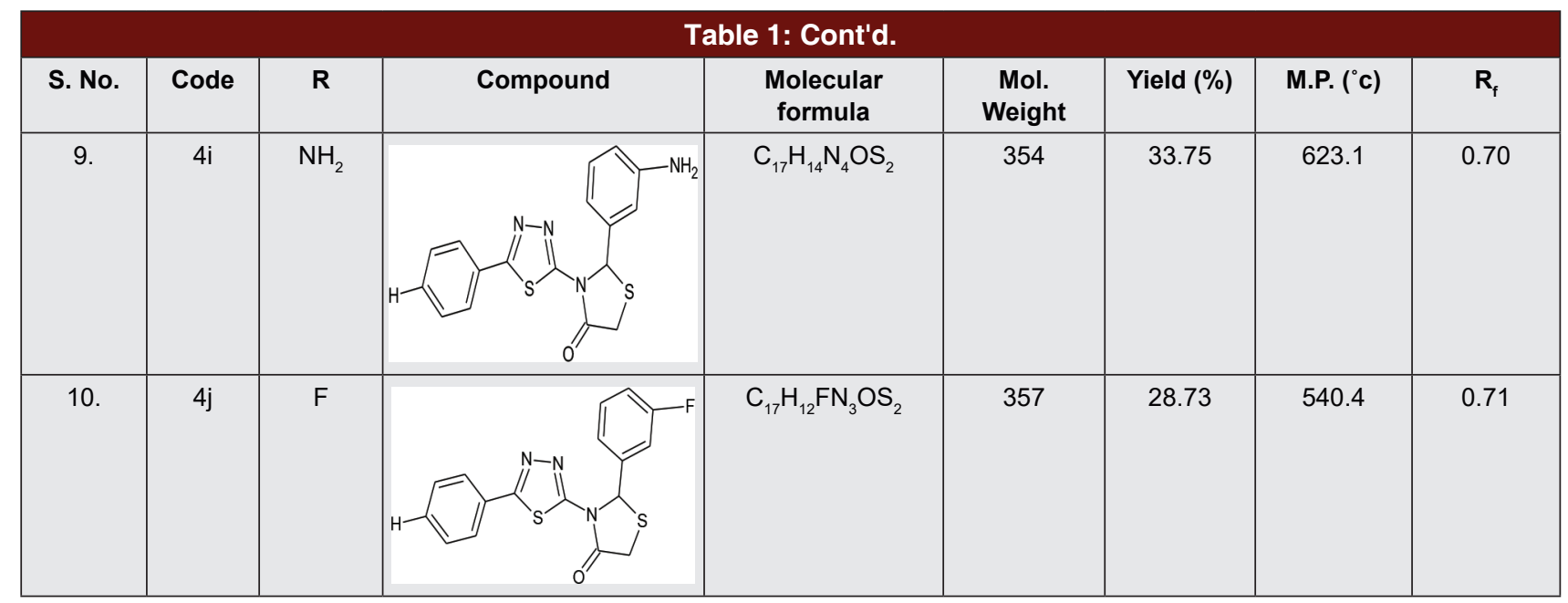

cytotoxic effect of different derivatives (4a-4j) in MCF-7 was exposed to have superior inhibitory potential. Anticancer assessment of various derivatives results indicated that compounds 2-(4-aminophenyl)-3-(5-phenyl-1,3,4-thiadiazol-2-yl)thiazolidin-4-one (4i), 2-(4-(dimetbylamino)phenyl)-3-(5-phenyl-1,3,4-thiadiazol-2-yl)thiazolidin-4-one (4b), 2-(4-hydroxyphenyl)-3-(5-phenyl-1,3,4-thiadiazol-2-yl)thiazolidin-4-one (4f) and 2-phenyl-3-(5-phenyl-1,3,4-thiadiazol-2-yl) thiazolidin-t-one (4a) were the most intense cytotoxic specialists. According to obtained results, it was concluded that the most specific and effective activity of the derivatives, found on those derivative having groups like amine, hydrogen moiety, hydroxyl group at the phenyl ring of thiazolidin-4-one, as the compare with others. Similarly, other derivatives having following functional moiety i.e. $\mathrm{NO}_{2}$, Chloro, fluoro, $\mathrm{CH}_{3}$ also suggested anticancer activity. ${ }^{5,33}$

\section{Antimicrobial activity}

Thiadiazole system in the side chain linked to the thiazolidinone moiety helps, $(4 \mathrm{a}-4 \mathrm{j})$, the compounds to show antimicrobial activity, at a concentration value of $0.025-2500 \mu \mathrm{g} / \mathrm{ml}$. The two sections (the thiazolidinone part and the thiadiazole part) have been accounted for to have a huge wide range of antimicrobial exercises which may add to the great outcomes got from testing them as antibacterial operations. In addition, replacement of the distal phenyl aromatic ring from thiazolidinone moieties with various grouping at the second position may likewise help in getting such great outcomes. ${ }^{34,35}$ As our result shows all the compounds are active and show antimicrobial against all the strains. It was inter esting to observe that some compounds (4a, 4b, 4f and 4i) have shown activity that is very near to the standard drugs (shown in Table 2 and 3).

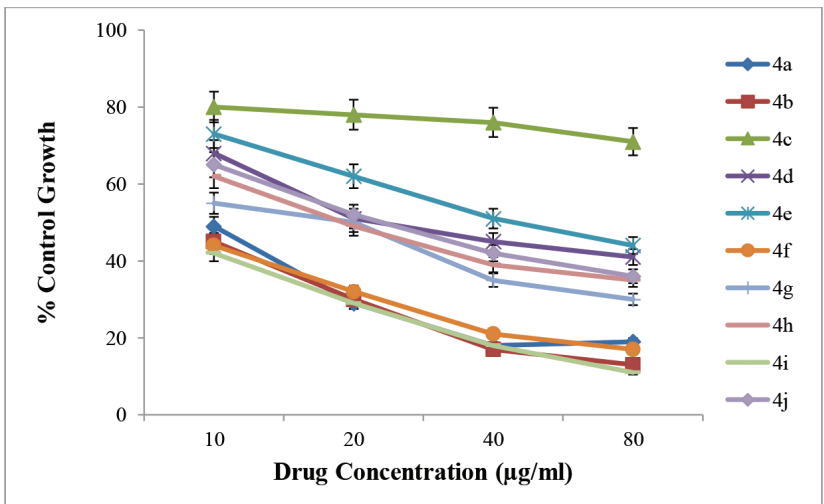

Figure 2: In-vitro anticancer study of different derivatives in MCF-7 cancer cellline.

The increased activity of the new derivatives can be explained that they act as more powerful and potent microbicidal agents, thus killing more of the bacteria and fungi than the standard drug. This is might be the result of the lipophilic character, which favors its permeation through the lipid layer of the microbial membranes. The existence of imino linkage $(-\mathrm{N}=\mathrm{C}-)$ in the compounds is essential for the enhancement of antibacterial and antimicrobaial activities. ${ }^{36}$

\section{Anti-inflammatory activity}

Analogs also show encouraging results against antiinflammatory activity. All the compounds $(4 a-4 j)$ were screened for anti-inflammatory activity, using ibuprofen as a reference drug. All the tested compounds exhibit good activity. Compound $4 \mathrm{i}$, which was substituted by $\mathrm{NH}_{2}$ group at the C-2 position of thiazolidin- $4(3 \mathrm{H})-$ one moiety is the most active compound, among all the tested compounds showed $58.64 \%$ potency and 


\section{Table 2: Anti-bacterial bio-assay of synthesized compounds.}

\begin{tabular}{|c|c|c|c|c|c|c|c|c|}
\hline \multirow[t]{2}{*}{ Compounds } & \multicolumn{2}{|c|}{$\begin{array}{c}\text { Bacteria } \\
2500\end{array}$} & \multicolumn{6}{|c|}{$\begin{array}{l}\text { Diameter of the zone (in } \mathrm{mm} \text { ) as per Concentration Placed in } \\
\text { agar well (in } \mu \mathrm{g} / \mathrm{ml} \text { ) }\end{array}$} \\
\hline & & & 250 & 25 & 2.5 & 0.25 & 0.025 & \\
\hline \multirow[t]{4}{*}{$4 a}$. & \multirow[t]{2}{*}{ Gram-ve } & $P$. aeruginosa & 22 & 15 & 11 & - & - & - \\
\hline & & E. coli & 20 & 13 & 10 & & & \\
\hline & \multirow[t]{2}{*}{ Gram+ve } & S. aureus & 21 & 16 & 11 & - & - & - \\
\hline & & S. pyogenes & 20 & 16 & 12 & & & \\
\hline \multirow[t]{4}{*}{ 4b. } & \multirow[t]{2}{*}{ Gram-ve } & $P$. aeruginosa & 26 & 22 & 16 & 13 & - & - \\
\hline & & E. coli & 22 & 15 & 10 & & - & - \\
\hline & \multirow[t]{2}{*}{ Gram+ve } & S. aureus & 23 & 17 & 10 & - & - & - \\
\hline & & S. pyogenes & 24 & 19 & 11 & - & - & - \\
\hline \multirow[t]{4}{*}{ 4c. } & \multirow[t]{2}{*}{ Gram-ve } & $P$. aeruginosa & 22 & 17 & 11 & - & - & - \\
\hline & & E. coli & 19 & 13 & 10 & - & - & - \\
\hline & \multirow[t]{2}{*}{ Gram+ve } & S. aureus & 20 & 15 & 11 & - & - & - \\
\hline & & S. pyogenes & 21 & 15 & 12 & - & - & - \\
\hline \multirow[t]{4}{*}{ 4d. } & \multirow[t]{2}{*}{ Gram-ve } & $P$. aeruginosa & 21 & 17 & 12 & - & - & - \\
\hline & & E. coli & 18 & 16 & 9 & - & - & - \\
\hline & \multirow[t]{2}{*}{ Gram+ve } & S. aureus & 17 & 14 & 9 & - & - & - \\
\hline & & S. pyogenes & 17 & 13 & 8 & - & - & - \\
\hline \multirow[t]{4}{*}{$4 e}$. & \multirow[t]{2}{*}{ Gram-ve } & P.aeruginosa & 16 & 12 & 9 & - & - & - \\
\hline & & E. coli & 15 & 10 & 9 & - & - & - \\
\hline & \multirow[t]{2}{*}{ Gram+ve } & S. aureus & 14 & 10 & 10 & - & - & - \\
\hline & & S. pyogenes & 15 & 9 & 8 & - & - & - \\
\hline \multirow[t]{4}{*}{ 4f. } & \multirow[t]{2}{*}{ Gram-ve } & P.aeruginosa & 23 & 17 & 15 & 9 & - & - \\
\hline & & E. coli & 22 & 14 & 12 & - & - & - \\
\hline & \multirow[t]{2}{*}{ Gram+ve } & S. aureus & 21 & 15 & 11 & - & - & - \\
\hline & & S. pyogenes & 23 & 15 & 10 & 6 & - & - \\
\hline \multirow[t]{4}{*}{$4 \mathrm{~g}$. } & Gram-ve & $P$. aeruginosa & 20 & 14 & 10 & - & - & - \\
\hline & & E. coli & 20 & 13 & 9 & - & - & - \\
\hline & Gram+ve & S. aureus & 19 & 14 & - & - & - & - \\
\hline & & S. pyogenes & 21 & 15 & 11 & - & - & - \\
\hline $4 \mathrm{~h}$. & Gram-ve & $P$. aeruginosa & 19 & 14 & 10 & - & - & - \\
\hline & & E. coli & 19 & 12 & 8 & - & - & - \\
\hline & Gram+ve & S. aureus & 20 & 15 & 11 & - & - & - \\
\hline & & S. pyogenes & 18 & 12 & - & - & - & - \\
\hline $4 i$. & Gram-ve & $P$. aeruginosa & 26 & 20 & 18 & 9 & - & - \\
\hline & & E. coli & 26 & 18 & 12 & - & - & - \\
\hline & Gram+ve & S. aureus & 24 & 16 & 11 & - & - & - \\
\hline & & S. pyogenes & 25 & 17 & 12 & 7 & - & - \\
\hline $4 \mathrm{j}$. & Gram-ve & $P$. aeruginosa & 19 & 14 & 11 & - & - & - \\
\hline & & E. coli & 18 & 15 & 9 & - & - & - \\
\hline & Gram+ve & S. aureus & 20 & 14 & 10 & - & - & - \\
\hline & & S. pyogenes & 19 & 14 & 11 & - & - & - \\
\hline Ampiciline & Gram-ve & $P$. aeruginosa & 26 & 21 & 17 & 12 & - & - \\
\hline & & E. coli & 24 & 19 & 10 & - & - & - \\
\hline & Gram+ve & S. aureus & 25 & 19 & 11 & - & - & - \\
\hline & & S. pyogenes & 25 & 18 & 12 & 8 & - & - \\
\hline
\end{tabular}




\begin{tabular}{|c|c|c|c|c|c|c|c|}
\hline \multirow[t]{2}{*}{ Compounds } & \multirow[t]{2}{*}{ Fungi } & \multicolumn{6}{|c|}{ Diameter of zone (in $\mathrm{mm}$ ) as per Concentration Placed in agar well (in $\mu \mathrm{g} / \mathrm{ml}$} \\
\hline & & 2500 & 250 & 25 & 2.5 & 0.25 & 0.025 \\
\hline \multirow[t]{2}{*}{ 4a. } & A. niger & 21 & 16 & 11 & - & - & - \\
\hline & C. albicans & 22 & 17 & 13 & 8 & - & - \\
\hline \multirow[t]{2}{*}{ 4b. } & A. niger & 24 & 20 & 15 & 10 & - & - \\
\hline & C. albicans & 23 & 18 & 12 & - & - & - \\
\hline \multirow[t]{2}{*}{ 4c. } & A. niger & 22 & 15 & - & - & - & - \\
\hline & C. albicans & 17 & 14 & 10 & - & - & - \\
\hline \multirow[t]{2}{*}{$4 d$} & A. niger & 22 & 15 & - & - & - & - \\
\hline & C. albicans & 17 & 14 & 10 & - & - & - \\
\hline \multirow[t]{2}{*}{$4 e}$. & A. niger & 19 & 15 & 10 & - & - & - \\
\hline & C. albicans & 21 & 16 & 11 & - & - & - \\
\hline \multirow[t]{2}{*}{$4 f}$. & A. niger & 22 & 16 & 12 & - & - & - \\
\hline & C. albicans & 20 & 15 & 12 & - & - & - \\
\hline \multirow[t]{2}{*}{$4 \mathrm{~g}}$. & A. niger & 20 & 18 & 11 & - & - & - \\
\hline & C. albicans & 22 & 17 & 13 & - & - & - \\
\hline \multirow[t]{2}{*}{$4 \mathrm{~h}}$. & A. niger & 20 & 17 & 12 & - & - & - \\
\hline & C. albicans & 18 & 14 & 10 & - & - & - \\
\hline \multirow[t]{2}{*}{$4 i}$. & A. niger & 25 & 19 & 13 & 8 & - & - \\
\hline & C. albicans & 23 & 17 & 12 & - & - & - \\
\hline \multirow[t]{2}{*}{$4 \mathrm{j}}$. & A. niger & 20 & 14 & 10 & - & - & - \\
\hline & C. albicans & 23 & 17 & 11 & - & - & - \\
\hline \multirow[t]{2}{*}{ Miconazole } & A. niger & 25 & 19 & 14 & - & - & - \\
\hline & C. albicans & 22 & 17 & 14 & 10 & - & - \\
\hline
\end{tabular}

(- = not active)

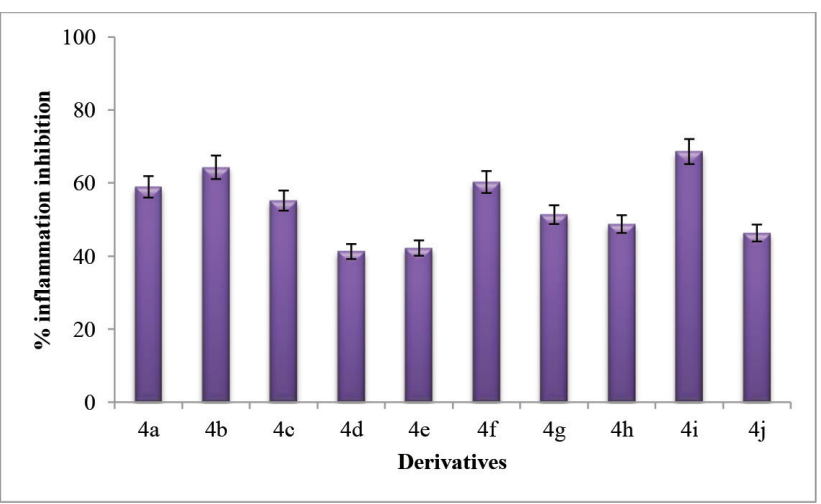

Figure 3: Anti-inflammatory activity of different derivatives.

Compound $4 \mathrm{~d}$, exhibit lower percentage inhibition of edema which is $41.27 \%$ (as shown in Figure 3). The significant activity may be due to the presence of electron-withdrawing group in the $2^{\text {nd }}$ position of thiazolidinone nucleus. ${ }^{37}$

\section{Molecular docking study}

The data obtained from the docking study between ligand and protein molecule was depicted in Table 4 and also illustration was summarized in Figure 4. According to the above results, it was found that the compound synthesized derivative $4 \mathrm{i}$, signifies the effective binding confirmation (score- $128.488 \mathrm{kcal} / \mathrm{mol}$ ) with highly negative bonding charges (-28.09) with the human DHFR, which is near to Methotrexate $168 \mathrm{~K} . \mathrm{cal} / \mathrm{mol}$, the docking pattern also revealed the compound $4 \mathrm{i}$ fitted well in the active site pocket. As the study, among other derivatives, also possess their significant binding score and their active participation with DHFR. From the derivative $4 \mathrm{i}$, the three hydrogen $(\mathrm{H})$ bond was formed with DHFR, the first hydrogen bond is formed with the amino acid ALA9 of the DHFR with the 38th hydrogen of derivative $4 \mathrm{i}$ (4i:H38 - A:ALA9:O) with $\mathrm{H}$-distance $2.47400 \mathrm{~A}^{0}$. In the next two more H-bond was formed with ALA9 (A:ALA9:HN - 4i:H36) and TYR (4i:H35 - A:TYR121:OH) with a hydrogen bond distance $1.63900 \mathrm{~A}^{0}$ and $1.91300 \mathrm{~A}^{0}$ respectively. (Figure 5). Interaction of compound $4 \mathrm{c}$ was not been obtained, for that, the docking data and Figure not been represented.

\section{ADMET study}

The results are determined by utilizing standard parameters provided by DS. The results are given in Table 5 


\section{Table 4: Docking scores of the compounds (A1 4a-4J) with human DHFR (PDB ID:1DLF) in comparison with} Methotrexate) docking score.

\begin{tabular}{|c|c|c|c|c|c|}
\hline Name & $\begin{array}{l}\text { Libdock } \\
\text { Score }\end{array}$ & $\begin{array}{l}\text { Interacting } \\
\text { Amino Acids }\end{array}$ & $\begin{array}{l}\text { Binding } \\
\text { Energy }\end{array}$ & Interacting Atoms & H-Distance \\
\hline $4 f$ & 119.714 & $\begin{array}{c}\text { ILE7, Val8, Ala9, Tyr121, } \\
\text { Val115, Arg70, Asn64, } \\
\text { SER59, Phe34, Phe31, Glu30, GIn35, Thr136 }\end{array}$ & -14.73122 & $\begin{array}{c}\text { 4f:H37 - A:SER59:OG } \\
\text { A:ALA9:HN - 4f:O17 } \\
\text { A:PHE31:CZ - 4f:H25 }\end{array}$ & $\begin{array}{l}2.476000 \\
2.164000 \\
2.104000\end{array}$ \\
\hline $4 e$ & 127.686 & $\begin{array}{c}\text { ILE7, Val8, Ala9, Tyr121, } \\
\text { Val115, Arg70, Asn64, SER59, Phe34, Phe31, } \\
\text { Glu30, GIn35, Thr136 }\end{array}$ & 37.90698 & $\begin{array}{l}\text { A:ALA9:HN - 4e:O17 } \\
\text { 4e:H27 - A:PHE31:CZ } \\
\text { 4e:H34 - A:TYR121:OH }\end{array}$ & $\begin{array}{l}1.967000 \\
2.142000 \\
1.973000\end{array}$ \\
\hline $4 \mathrm{~h}$ & 117.664 & $\begin{array}{c}\text { ILE7, Val8, Ala9, Tyr121, } \\
\text { Val115, Arg70, Asn64, SER59, Phe34, Phe31, } \\
\text { Glu30, GIn35, Thr136 }\end{array}$ & -4.98231 & $\begin{array}{l}\text { A:ALA9:HN - 4h:O17 } \\
\text { 4h:H25 - A:PHE31:CZ }\end{array}$ & $\begin{array}{l}2.198000 \\
2.116000\end{array}$ \\
\hline $4 i$ & 128.488 & $\begin{array}{c}\text { ILE7, Val8, Ala9, Tyr121, } \\
\text { Val115, Arg70, Asn64, SER59, Phe34, Phe31, } \\
\text { Glu30, GIn35, Thr136 }\end{array}$ & -28.09996 & $\begin{array}{c}\text { 4i:H38 - A:ALA9:O } \\
\text { A:ALA9:HN - 4i:H36 } \\
\text { 4i:H35 - A:TYR121:OH }\end{array}$ & $\begin{array}{l}2.474000 \\
1.639000 \\
1.913000\end{array}$ \\
\hline $4 b$ & 127.381 & $\begin{array}{c}\text { ILE7, Val8, Ala9, Tyr121, } \\
\text { Val115, Arg70, Asn64, SER59, Phe34, Phe31, } \\
\text { Glu30, GIn35, Thr136 }\end{array}$ & -17.31804 & 4b:H34 - A:PHE31:CE1 & 2.165000 \\
\hline $4 a$ & 119.185 & $\begin{array}{c}\text { ILE7, Val8, Ala9, Tyr121, } \\
\text { Val115, Arg70, Asn64, SER59, Phe34, Phe31, } \\
\text { Glu30, GIn35, Thr136 }\end{array}$ & -12.57253 & 4a:H34 - A:TYR121:OH & 1.961000 \\
\hline $4 c$ & 127.345 & $\begin{array}{c}\text { ILE7, Val8, Ala9, Tyr121, } \\
\text { Val115, Arg70, Asn64, SER59, Phe34, Phe31, } \\
\text { Glu30, Gln35, Thr136 }\end{array}$ & -24.27834 & No interactions & \\
\hline $4 d$ & 125.194 & $\begin{array}{c}\text { ILE7, Val8, Ala9, Tyr121, } \\
\text { Val115, Arg70, Asn64, SER59, Phe34, Phe31, } \\
\text { Glu30, GIn35, Thr136 }\end{array}$ & 11.15526 & A:ALA9:HN - 4d:H36 & 1.595000 \\
\hline $4 \mathrm{~g}$ & 128.106 & $\begin{array}{c}\text { ILE7, Val8, Ala9, Tyr121, } \\
\text { Val115, Arg70, Asn64, SER59, Phe34, Phe31, } \\
\text { Glu30, GIn35, Thr136 }\end{array}$ & -4.98231 & $\begin{array}{l}\text { A:ALA9:HN - 4g:C23 } \\
\text { A:ALA9:HN - 4g:H37 }\end{array}$ & $\begin{array}{l}2.173000 \\
1.302000\end{array}$ \\
\hline $4 j$ & 126.234 & $\begin{array}{c}\text { ILE7, Val8, Ala9, Tyr121, } \\
\text { Val115, Arg70, Asn64, SER59, Phe34, Phe31, } \\
\text { Glu30, GIn35, Thr136 }\end{array}$ & -2.62483 & 4j:H36 - A:ALA9:HN & 1.556000 \\
\hline
\end{tabular}

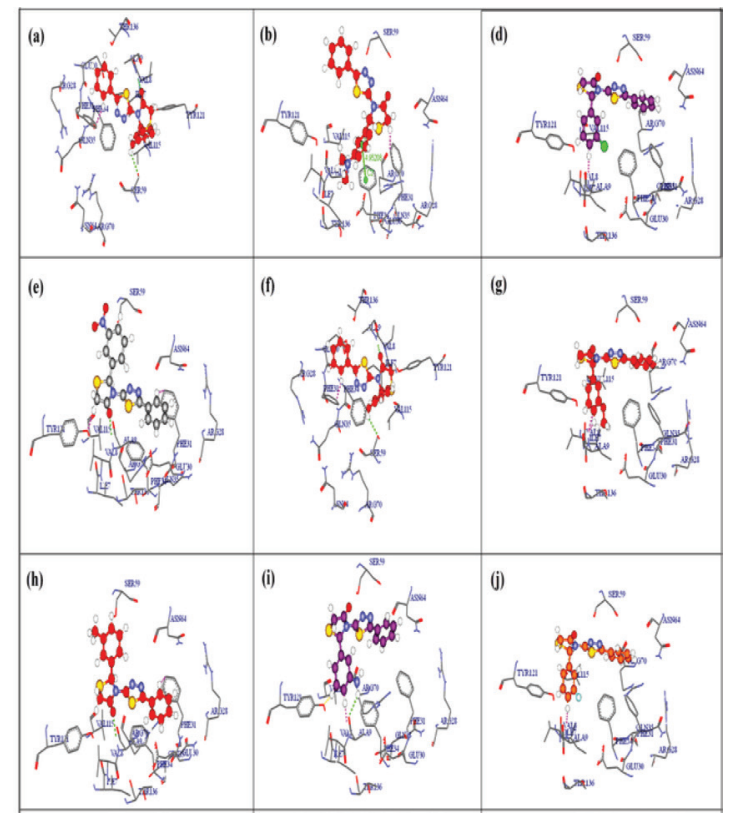

Figure 4: Receptor-ligand Hydrogen bonding interactions of 4(a-j) compound with active site residues of human DHFR.

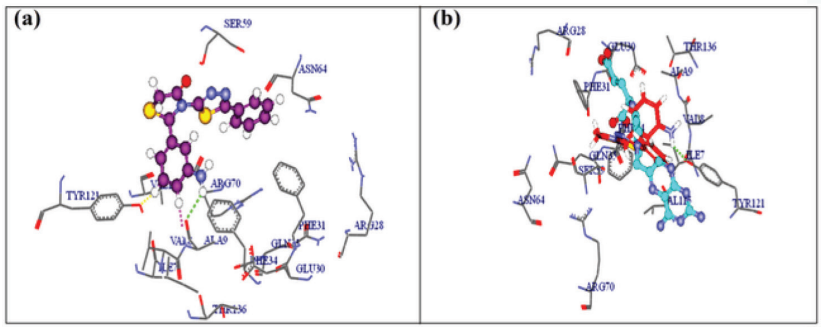

Figure 5: (a) Receptor-ligand Hydrogen bonding interactions of $4 \mathrm{i}$ compound with active site residues of human DHFR (Green dotted lines-Hydrogen bonds, Pink Colour-Bumps); (b) Superimposition of methotrexate with $4 \mathrm{i}$ compound in active site pocket (methotrexate represented as Ball-stick and Stick mode 4i).

and Figure 6. As per DS parameters, standard values like level 0 for human intestinal absorption, 3 and 4 for the solubility. While level 0 for non-inhibitory feature with CYP450 2D6, 3 for the BBB penetration and 0 for the non-toxicity nature were checked for acquiring drug substances. Figure 6 displays the predicted values 


\begin{tabular}{|c|c|c|c|c|c|c|c|}
\hline Compound & $\begin{array}{c}\text { ADMET } \\
\text { BBB Level }\end{array}$ & $\begin{array}{c}\text { ADMET } \\
\text { Absorp-tion } \\
\text { Level }\end{array}$ & $\begin{array}{c}\text { ADMET } \\
\text { Solubility } \\
\text { Level }\end{array}$ & $\begin{array}{l}\text { ADMET } \\
\text { Hepato- } \\
\text { toxicity }\end{array}$ & $\begin{array}{l}\text { ADMET } \\
\text { CYP2D6 }\end{array}$ & $\begin{array}{c}\text { ADMET } \\
\text { PPB Level }\end{array}$ & $\begin{array}{c}\text { ADMET } \\
\text { AlogP98 }\end{array}$ \\
\hline $4 a$ & 1 & 0 & 2 & 1 & 0 & 2 & 4.104 \\
\hline $4 b$ & 1 & 0 & 2 & 0 & 1 & 2 & 4.266 \\
\hline $4 c$ & 1 & 0 & 2 & 0 & 1 & 2 & 4.158 \\
\hline $4 d$ & 1 & 0 & 1 & 1 & 0 & 2 & 4.769 \\
\hline $4 e$ & 2 & 0 & 2 & 1 & 0 & 2 & 3.999 \\
\hline $4 f$ & 1 & 0 & 2 & 1 & 0 & 2 & 3.862 \\
\hline $4 \mathrm{~g}$ & 1 & 0 & 2 & 1 & 1 & 2 & 4.088 \\
\hline $4 \mathrm{~h}$ & 1 & 0 & 2 & 1 & 0 & 2 & 4.59 \\
\hline $4 i$ & 2 & 0 & 2 & 1 & 0 & 2 & 3.358 \\
\hline $4 j$ & 1 & 0 & 2 & 1 & 0 & 2 & 4.31 \\
\hline
\end{tabular}

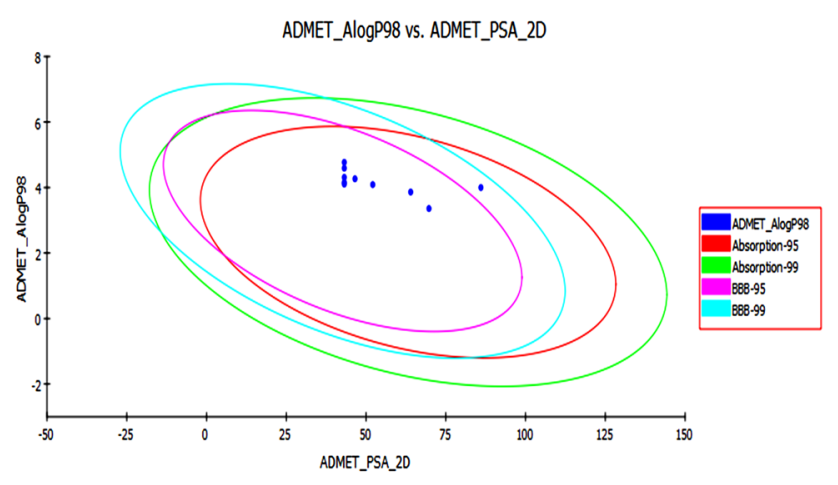

Figure 6: Plot of PSA vs Log.

plot of drug absorption for the compounds. The $\mathrm{X}$-axis denotes the compound's solubility and Y-axis denotes the $\log P$ values. ADMET Descriptors, the 2D polar surface area in A2 is plotted against ALogP98. The space occupied by the ellipse indicates absorption without violating ADMET features. Ellipses denote the model at $95-99 \%$ confidence limit to the absorption models of BBB and intestinal.

\section{CONCLUSION}

Most of the therapeutic agents are heterocyclic compounds; hence heterocyclic chemistry has been the most fruitful area for drug discovery. Based on this fact, the present investigation was planned. According to the literature survey it found that thiazolidinone compound have wide varieties of biological activities like hypnotic, antitussive, analgesic, muscle relaxant, anticonvulsant, antiallergic, antibacterial, hypoglycemic and antispasmodic. So, considerable interest has been found in thiazolidinone compounds in search of potential drugs. Small changes in thiazolidinone can convert it into 2,3-disubstituted thiazolidinone and the biological activity can be enhanced with the introduction of the 1,3,4-thiadiazole. According to results, the derivatives of the principle compound can be synthesized in a stable and solid crystalline form. The synthesized derivatives were then confirmed by FT-IR, Melting point and NMR spectrometer and screened for biological evaluation. All the derivatives are effective as bioactive agent. Overall, this study provides sound evidence that our synthesized compounds can be converted and then use as a suitable dosage form because they possess favorable characteristics amenable to further development towards commercial application.

\section{ACKNOWLEDGEMENT}

The author acknowledges SAIF-Central Drug Research Institute Lucknow (UP) for providing NMR spectral study. The author also contributes their special thanks to ACTREC-TMH, Mumbai for providing in-vitro anticancer study.

\section{CONFLICT OF INTEREST}

The authors declare no conflict of interest.

\section{REFERENCES}

1. Singh TP, Sharma PK, Kaur PK, Mondal SC, Gupta A. Pharmacological evaluation of thiazolidinone derivatives: a prespective review. Pharm Chem. 2011;31:194-206.

2. Mulay A. Exploring potential of 4-thiazolidinone: a brief review. Int J Pharm Pharm Sci. 2009;1(1):47-64.

3. Singh SP, Parmar SS, Raman K, Stenberg VI. Chemistry and biological activity of thiazolidinones. Chem Rev. 1981;81(2):175-203. doi: 10.1021/ cr00042a003. 
4. Verma A, Saraf SK. 4-thiazolidinone--a biologically active scaffold. Eur J Med Chem. 2008;43(5):897-905. doi: 10.1016/j.ejmech.2007.07.017, PMID 17870209.

5. Joseph A, Shah CS, Kumar SS, Alex AT, Maliyakkal N, Moorkoth S, Mathew JE. Synthesis, in vitro anticancer and antioxidant activity of thiadiazole substituted thiazolidin-4-ones. Acta Pharm. 2013;63(3):397-408. doi: 10.2478/acph-2013-0028, PMID 24152899.

6. El-Sayed WA, Abdel-Monem YK, Yousif NM, Tawfek N, Shaaban MT, AbdelRahman AAH. Antimicrobial activity of new 2,4-Disubstituted Thiazolidinone derivatives. Z Naturforsch C J Biosci. 2009;64(11-12):785-9. doi: 10.1515/ znc-2009-11-1205, PMID 20158146.

7. Nagarajan SR, De Crescenzo GA, Getman DP, Lu HF, Sikorski JA, Walker JL, McDonald JJ, Houseman KA, Kocan GP, Kishore N, Mehta PP, FunkesShippy CL, Blystone L Discovery of novel benzothiazolesulfonamides as potent inhibitors of HIV-1 protease. Bioorg Med Chem. 2003;11(22):4769-77. doi: 10.1016/j.bmc.2003.07.001. PMID 14556792.

8. Ergenç N, Capan G. Synthesis and anticonvulsant activity of new 4-thiazolidone and 4-thiazoline derivatives. Farmaco. 1994;49(6):449-51. PMID 8074788.

9. Kato T, Ozaki T, Ohi N. Improved synthetic methods of CP-060S, a novel cardioprotective drug. Tetrahedron Asymmetry. 1999;10(20):3963-68. doi: 10.1016/S0957-4166(99)00441-3.

10. Asati K, Srivastava SK, Srivastava SD. Synthesis of thiazolidinones arylidenes and their biological activity: analgesic and antifungal. Chem Indian J. 2005;1(10):667-72.

11. Parmar K, Prajapati S, Patel R, Patel R. A simple and efficient procedure for biologically active 1,2,4-triazolo-[3,4-b]-1,3,4-thiadiazole-2-aryl-thiazolidine4-one derives. Res J Chem Sci. 2011;1:18-24.

12. Tao J, Wang DZ, Cao LH. Synthesis of 5-(6-Pyridazinone-3-yl)-2-glycosylamino1,3,4-thiadiazoles. Jnl Chinese Chemical Soc. 2010;57(5A):1077-80. doi: 10.1002/jccs.201000151.

13. Hadizadeh F, Vosooghi R. Synthesis of $\alpha$-[5-(5-amino-1,3,4-thiadiazol-2-yl)2-imidazolylthio]acetic acids. J Heterocycl Chem. 2008;45(5):1477-9. doi: 10.1002/jhet.5570450537.

14. Foroumadi A, Asadipour A, Mirzaei M, Karimi J, Emami S. Antituberculosis agents. V. Synthesis, evaluation of in vitro antituberculosis activity and cytotoxicity of some 2-(5-nitro-2-furyl)-1,3,4-thiadiazole derivatives. Farmaco. 2002;57(9):765-9. doi: 10.1016/s0014-827x(02)01277-6, PMID 12385528.

15. Ciotti MM, Humphreys SR, Venditti JM, Kaplan NO, Goldin A. The antileukemic action of two thiadiazole derivatives. Cancer Res. 1960;20(8):1195-201. PMID 13693712.

16. Jain SK, Mishra P. 3D-QSAR of 2,5,-disubstituted-1,3,4-thiadiazole derivatives as diuretic agents. J Computational Method Mol Des. 2011;1(1):52-8.

17. Murugan R, Anbazhagan S, Lingeshwaran SS, Sriman Narayanan S. Synthesis and in vivo antidiabetic activity of novel dispiropyrrolidines through [3+2] cycloaddition reactions with thiazolidinedione and rhodanine derivatives. Eur J Med Chem. 2009;44(8):3272-9. doi: 10.1016/j.ejmech.2009.03.035, PMID 19395129.

18. Padhy AK, Nag VL, Panda CS. Studies on the synthesis and bioactivity of some thiadiazole derivatives. Ind J Chem. 1999;38B:998-1001.

19. Fatah ME. Synthesis and investigation of mass spectra of 3-substituted-2thioxo-imidazolidin-4-one derivatives. Ind J Chem. 2006;45B:2523-33.

20. Belen'kii L, Poddubny I, Krayushkin M. Synthesis of 2-amino-5-aryl-1,3,4thiadiazoles from trichloromethylarenes: the effect of reaction conditions.
Phosphorus Sulfur Silicon Relat Elem. 1994;95(1-4):469-70. doi: 10.1080/10426509408034277.

21. Pandey A, Rajavel R, Chandraker S, Dash D. Synthesis of Schiff Bases of 2-amino-5-aryl-1,3,4-thiadiazole and its analgesic, anti-inflammatory and antibacterial activity. E-Journal of Chemistry. 2012;9(4):2524-31. doi: 10.1155/2012/145028.

22. Srivastava T, Gaikwad AK, Haq W, Sinha S, Kati SB. Synthesis and biological evaluation of 4-thiazolidinone derivatives as potential antimycobacterial agents. Arkivoc. 2005;ii:120-30.

23. Güzel O, Salman A. Synthesis and biological evaluation of new 4-thiazolidinone derivatives. J Enzyme Inhib Med Chem. 2009;24(4):1015-23. doi: 10.1080/14756360802608021, PMID 19624255.

24. Deep A, Narasimhan B, Lim SM, Ramasamy K, Mishra RK, Mani V. 4-Thiazolidinone derivatives: synthesis, antimicrobial, anticancer evaluation and QSAR studies. RSC Adv;6(111):109485-94. doi: 10.1039/C6RA23006G.

25. Vichai V, Kirtikara K. Sulforhodamine B colorimetric assay for cytotoxicity screening. Nat Protoc. 2006;1(3):1112-6. doi: 10.1038/nprot.2006.179, PMID 17406391.

26. Skehan P, Storeng R, Scudiero D, Monks A, McMahon J, Vistica D, Warren JT, Bokesch H, Kenney S, Boyd MR. New colorimetric cytotoxicity assay for anticancer-drug screening. J Natl Cancer Inst. 1990;82(13):1107-12. doi: 10.1093/jnci/82.13.1107, PMID 2359136.

27. Garg S, Garg A. Synthesis, characterization and biological evaluation of some novel 2, 3-disubstitued quinazolin-4-(3h)-ones. Int J Respir. 2017;5(6):111.

28. Winter CA, Risley EA, Nuss GW. Carrageenin-induced edema in hind paw of the rat as an assay for antiiflammatory drugs. Proc Soc Exp Biol Med. 1962;111:544-7. doi: 10.3181/00379727-111-27849, PMID 14001233.

29. Rao GK. Synthesis, Antitubercular and antibacterial activities of some quinazolinone analogs substituted with benzothiophene. Chem Sci J. 2015;6(2):1-4. doi: 10.4172/2150-3494.100092.

30. Sharma R, Devendra PN, Ganpat LT. Synthesis of various isoniazidothiazolidinones and their imidoxy derivatives of potential biological interest. Arkivoc. 2006;1:1-12.

31. Bansal RK. Heterocyclic chemistry. 4th ed, New age international, New Delhi 2009 pp. p. 1-4.

32. Joule JA, Mill K. Heterocyclic chemistry. 4th ed. Blacksmith publishing. 2004 p. p. 511-6.

33. Dawood KM, Eldebss TM, El-Zahabi HS, Yousef MH, Metz P. Synthesis of some new pyrazole-based 1,3-thiazoles and 1,3,4-thiadiazoles as anticancer agents. Eur J Med Chem. 2013;70:740-9. doi: 10.1016/j.ejmech.2013.10.042.

34. Gupta A, Mehra P, Dhar SK. Plasmodium falciparum origin recognition complex subunit 5: functional characterization and role in DNA replication foci formation. Mol Microbiol. 2008;69(3):646-65. doi: 10.1111/j.13652958.2008.06316.x, PMID 18554328.

35. Manjula AC. Screening of antibacterial activity of total soluble protein of mulberry varieties. Int J Curr Pharm Res. 2011;3(2):60-1.

36. Sharba AH, Al-Bayati RH, Rezki N, Aouad MR. Synthesis of thiadiazoles and 1,2,4-triazoles derived from cyclopropane dicarboxylic acid. Molecules. 2005;10(9):1153-60. doi: 10.3390/10091153, PMID 18007381.

37. Sahu R, Tiwari S, Kalyani G. Thiazolidinone based 2, 5-disubstituted-1, 3, 4-thiadiazole: synthesis and antimicrobial evaluation. Int J Pharm Pharm Sci. 2013;5:290-191. 
PICTORIAL ABSTRACT

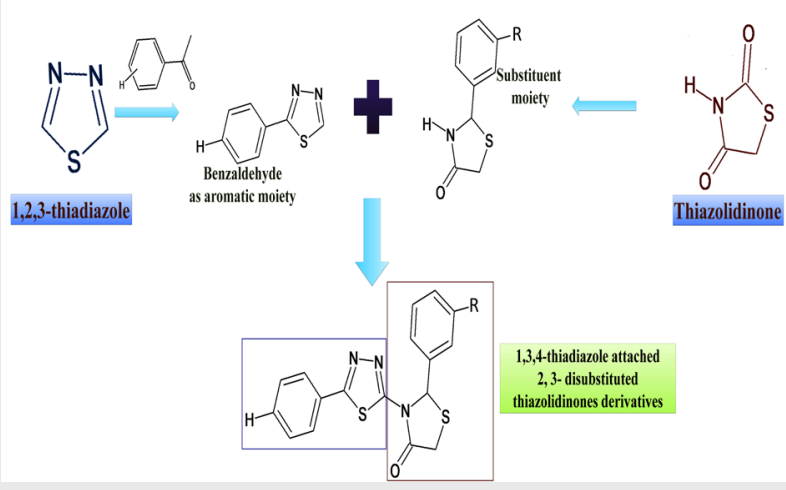

\section{SUMMARY}

- A set of conjugates (derivatives) were designed and synthesized and performed for anti-inflammatory, antimicrobial activity and anticancer activity.

- Synthesized derivative shows low toxicity and suggest potential agents for anti-inflammatory and antimicrobial activity.

- The data also suggested the effective anticancer potential of the synthesized derivatives, molecular docking and ADMET prediction studies supports the biological data.

\section{About Authors}

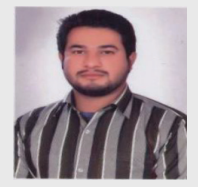

Dr. Ashish Garg, Department of PG Studies and Research in Chemistry and Pharmacy, Rani Durgawati University, Jabalpur, M.P. 482001, India.

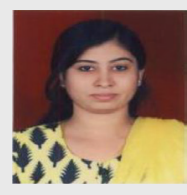

Dr. Sweta Garg, Shri Ram Institute of Pharmacy, Jabalpur, 482002, M.P., India.

Cite this article: Garg A, Garg S. 1,3,4-thiadiazole Attached 2, 3- disubstituted Thiazolidinones Derivatives: Synthesis and Biological Evaluation. Indian J of Pharmaceutical Education and Research. 2021;55(4):1151-63. 